\title{
APLIKASI RENTAL MOBIL DENGAN FITUR PELACAKAN GPS PADA CV. RAHAYU RENTAL KM 4.5 BANJARMASIN BERBASIS WEB
}

\author{
Muhammad Riyan' ${ }^{1}$, Andie ${ }^{2)}$, Muhammad Amin ${ }^{3)}$ \\ ${ }^{1}$ Fakultas Teknologi Informasi, Universitas Islam Kalimantan Muhammad Arsyad Al Banjari Banjarmasin \\ Email : andina777@gmail.com \\ ${ }^{2}$ Fakultas Teknologi Informasi, Universitas Islam Kalimantan Muhammad Arsyad Al Banjari Banjarmasin \\ Email : andina777@gmail.com \\ ${ }^{3}$ Fakultas Teknologi Informasi, Universitas Islam Kalimantan Muhammad Arsyad Al Banjari Banjarmasin \\ Email : maminbjm58@gmail.com
}

\begin{abstract}
Abstrack
CV. Rahayu Rental adalah suatu rental mobil yang berada di banjarmasin. Rental ini menyediakan pelayanan berupa sewa mobil harian, mingguan, bulanan bahkan bisa sampai tahunan. CV. Rahayu Rental beralamat di Jl. A. Yani Km. 4,5 Banjarmasin. Didalam usaha ini, masih banyak permasalahan yang terjadi pada bagian administrasi, yaitu pada proses pencatatan pemesanan sewa mobil yang memakan banyak waktu karena masih di catat melalui aplikasi desktop seperti Microsoft Office. Permasalahan juga terjadi pada saat pelanggan melakukan pemesanan melalui telepon, karena costumer tidak bisa melihat gambar mobil yang akan disewa. Proses pengolahan data dan pembuatan laporan yang terjadi di Rahayu Rental saat ini masih menggunakan pengolahan data yang bersifat pencatatan dalam bentuk pembukuan. Dengan semakin banyaknya jumlah produk dan transaksi yang terjadi setiap hari, cara tersebut ternyata menyulitkan perusahaan dalam proses pencarian data sehingga menyebabkan terjadinya keterlambatan bahkan kesalahan dalam mendapatkan informasi yang diinginkan. Juga pada masalah keamanan mobil rental, dengan tidak adanya sistem pelacakan maka mobil tidak dapat termonitor posisi sedang dimana, dan itu tentu dapat merugikan perusahaan jika terjadinya pencurian. Dengan beberapa permasalahan di atas, maka perlu dibuat aplikasi rental mobil dan dilengkapi pelacakaan GPS pada CV. Rahayu Rental sehingga dapat mempermudah dan memaksimalkan kinerja para pegawai, dan mengurangi resiko kerugian pada akhirnya penerapan aplikasi yang dianalisa pada penelitian ini diharapkan mendukung proses informasi yang dibutuhkan dengan cepat dan akurat. Aplikasi ini dibuat dengan bahasa pemrograman PHP dan MySQL. Model rekayasa perangkat lunak dengan metode Waterfall yang digunakan pada penelitian ini, berhasil mempermudah analisa perancangan sistem sesuai dengan tujuan penelitian.
\end{abstract}

Keyword: aplikasi, GPS, rental, sewa, web

\section{PENDAHULUAN}

Transportasi menjadi bagian penting dalam menunjang kecepatan dan efisiensi kerja pada masyarakat, tak jarang banyak orang memanfaatkan kendaraan darat sebagai angkutan paling digemari, mobil contohnya, selain dapat digunakan sesuka hati dimana akan beristirahat, juga dirasa cukup cepat sebagai angkutan yang dapat menyelesaikan mobilitas yang tinggi. Namun, bagi mereka yang tak mampu memiliki kendaraan pribadi, juga tak jarang mereka memanfaatkan rental mobil sebagai prasarana untuk menggunakan kendaraan darat.

Melihat dari kenyataan tersebut, rental mobil merupakan salah satu prasarana untuk menunjang kebutuhan masyarakat. Perusahaan yang menyediakan jasa rental mobil, kini pun semakin melambung tinggi, salah satunya adalah CV. Rahayu Rental. CV. Rahayu Rental adalah suatu rental mobil yang berada di Banjarmasin, tepatnya beralamat di Jl. A. Yani Km. 4,5 Banjarmasin. Rahayu Rental menyediakan pelayanan berupa sewa mobil harian, mingguan, bulanan bahkan bisa sampai tahunan. Perbedaan jenis mobil didasarkan pada tipe, harga, dan fasilitas yang ada di masingmasing mobil. Untuk mempromosikan mobilmobil yang akan disewakan serta memberikan informasi tentang Rahayu Rental ke pelanggan, perusahaan telah melakukan berbagai cara yaitu dengan saling memberi informasi melalui satu 
pelanggan ke pelanggan lainnya. Kemudian memperoleh informasi mengenai mobil yang belum disewa. Namun permasalahan muncul pada proses pencatatan pemesanan sewa mobil yang memakan banyak waktu karena masih di catat melalui aplikasi desktop seperti Microsoft Office. Permasalahan juga terjadi pada saat pelanggan melakukan pemesanan melalui telepon, karena kostumer tidak bisa melihat gambar mobil yang akan disewa. Proses pengolahan data dan pembuatan laporan yang terjadi di Rahayu Rental saat ini masih menggunakan pengolahan data yang bersifat pencatatan dalam bentuk pembukuan. Seluruh bukti pembayaran transaksi setiap hari dikumpulkan dan dilakukan pencatatan ke dalam buku besar transaksi untuk memudahkan pengolahan data transaksi. Setiap mobil yang diambil dan dikembalikan dicatat dalam buku mobil dengan tujuan mempermudah perusahaan melakukan pencarian data mobil ketika ada pelanggan yang akan melakukan pemesanan ataupun menanyakan persediaan jumlah produk. Dengan semakin banyaknya jumlah produk dan transaksi yang terjadi setiap hari, cara tersebut ternyata menyulitkan perusahaan dalam proses pencarian data sehingga menyebabkan terjadinya keterlambatan bahkan kesalahan dalam mendapatkan informasi yang diinginkan. Selain itu, hal tersebut menyebabkan keterlambatan dalam pembuatan laporan di perusahaan karena staf yang bersangkutan untuk membuat laporan harus mencari data-data yang telah diarsipkan sebelumnya. Kemudian dalam hal keamanan, untuk sekarang pada Rahayu Rental tidak adanya fitur pelacakan, sehingga admin tidak dapat melacak kenradaan atau posisi mobil.

Sejumlah penelitian yang telah dilakukan dalam membangun "Aplikasi Rental Mobil dengan Fitur Pelacakan GPS pada CV. Rahayu Rental" adalah diantaranya "Sistem Informasi Penyewaan Rental Mobil di CV. Surya Rental Mobil Bandung" oleh Andri Sahata Sitanggang Tahun 2017 dengan permasalahan pencatatan menggunakan media kertas yang rentan akan kehilangan data menyebabkan kesulitan dalam pencarian data yang dibutuhkan [2].

Kemudian pada penelitian Dedie Citra Mahendra Tahun 2017 yang berjudul "Sistem Monitoring Mobil Rental Menggunakan GPS Tracker" memiliki permasalahan banyaknya tingkat kriminal pencurian pada mobil rental [3].

Selanjutnya ialah berjudul "Sistem Informasi Manajemen Rental Mobil Berbasis Web" oleh Muhammad Hisyam Nuri pada tahun 2014 dengan permasalahan sulitnya proses transaksi antara pelanggan dan pengelola perusahaan, dan juga pelanggan tidak bisa melakukan booking dikarenakan tidak adanya fasilitas tersebut [4]

Oleh karena itu, berdasarkan dari permasalahan yang ada pada Rahayu Rental Banjarmasin, penulis ingin menganalisa sebuah aplikasi yang mampu mempermudah proses pengaksesan informasi dan pelacakan mobil pada Rahayu Rental.

\section{METODE PENELITIAN}

Teknik pengumpulan data yang akan digunakan pada penelitian ini adalah :

\section{a. Observasi}

Metode ini dilaksanakan dengan cara mengumpulkan data dengan meninjau langsung proses yang bejalan di CV. Rahayu Rental, pengumpulan data ini dilakukan dengan meneliti data yang meliputi data member, data mobil, data sopir, data perawatan mobil, data keuangan.

b. Wawancara

Pada tahap awal perancangan aplikasi ini, terlebih dahulu dilakukan wawancara dengan pihak-pihak terkait guna mendapatkan informasi tentang permasalahan dan kebutuhan aplikasi yang akan dirancang. Wawancara dilaksanakan dengan pihak dari CV. Rahayu Rental, dalam hal ini langsung kepada owner. Dari hasil wawancara yang telah dilaksanakan, diperoleh hasil sebagai berikut:

1) Rahayu Rental adalah suatu rental mobil yang berada di banjarmasin. Rahayu Rental menyediakan pelayanan berupa sewa mobil harian, mingguan, bulanan bahkan bisa sampai tahunan.

2) Rahayu Rental berdiri pada 2016 dan didirikan oleh M. Ryan Widodo.

c. Studi Kepustakaan

Dalam metode ini, penulis menggunakan buku-buku referensi ataupun informasi dari internet untuk mendapatkan 
teori-teori dan metodologi yang tepat untuk mendukung penelitian ini [1].

\section{Rancangan Model Sistem}

Pada rancangan model sistem ini akan membahas gambaran kebutuhan sistem yang akan dibangun. Pemodelan rancangan sistem ini menggunakan UML (Unified Modelling Language) yang memiliki beberapa tahap yaitu use case diagram, activity diagram, sequence diagram, dan class diagram.

\section{Use Case Diagram}

Pada bagian use case diagram akan membahas alur skenario hubungan antara user dan sistem, pada use case diagram ini membahas kebutuhan sistem dari sudut pandang user/pengguna.

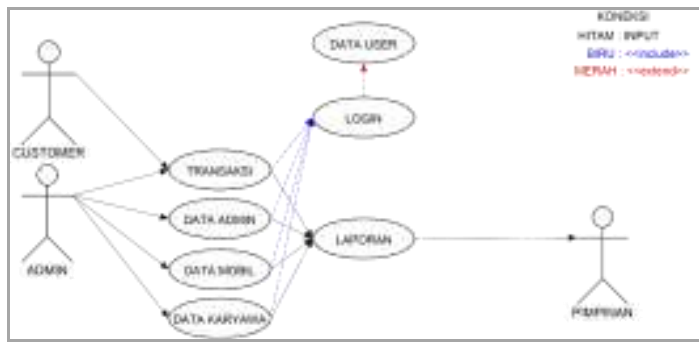

Gambar 1. Use Case Diagram

Activity diagram dari usecase diagram aplikasi rental mobil pada CV. Rahayu Rental Banjarmasin adalah sebagai berikut :

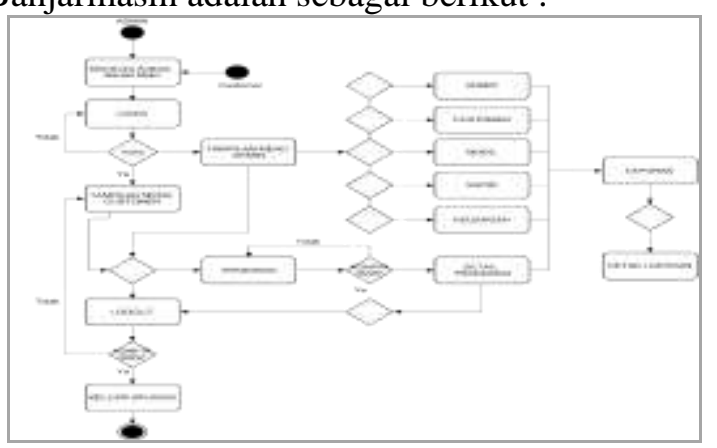

Gambar 2. Activity Diagram

1. Activity Diagram Admin

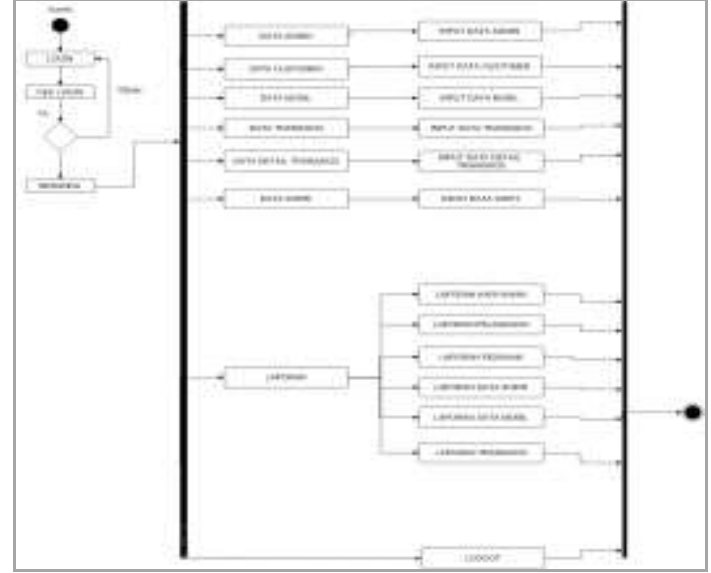

Gambar 3. Activity Diagram Admin

2. Activity Pelanggan

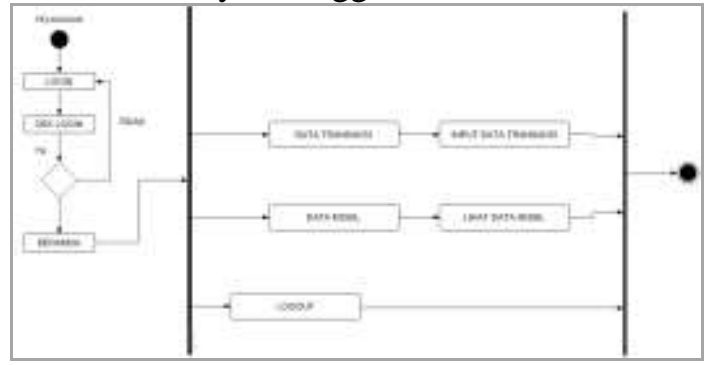

Gambar 4. Activity Diagram Pelanggan

\section{Sequence Diagram}

Sequence diagram merupakan gambaran interaksi antar objek dalam sistem seperti pengguna, tampilan dan sebagainya berupa pengiriman serangkaian data antar objek.

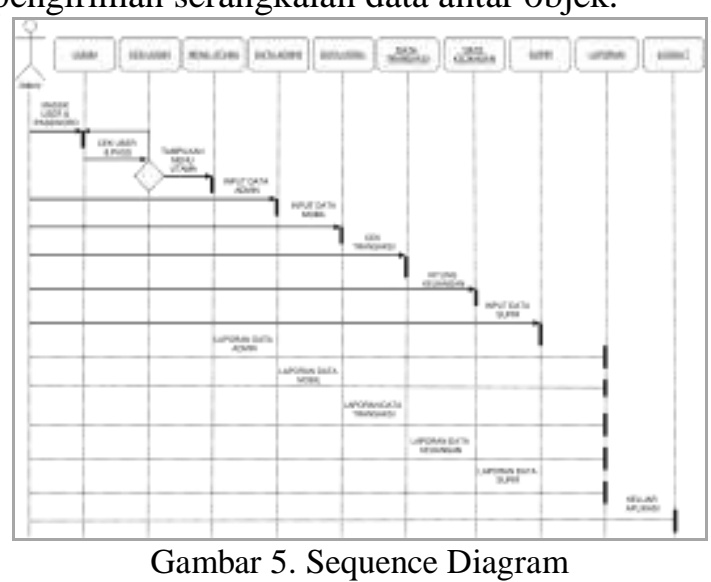

Class diagram mendeskripsikan jenis-jenis objek dalam sistem dan berbagai macam hubungan statis yang terdapat diantara mereka. Class diagram aplikasi rental mobil pada CV. Rahayu Rental Banjarmasin dapat dilihat pada gambar dibawah ini : 


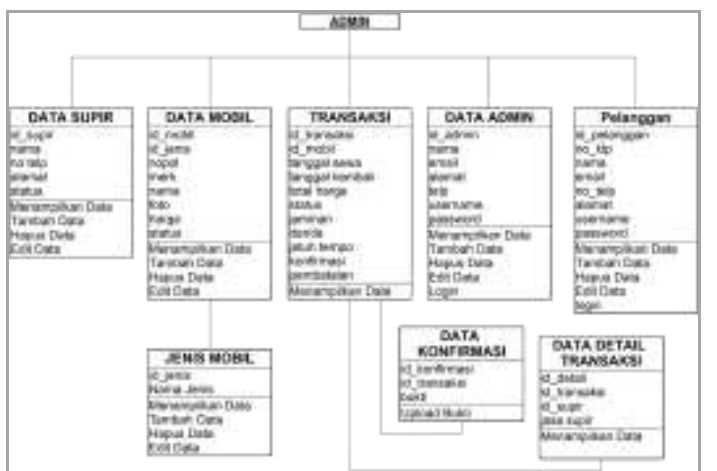

Gambar 6. Class Diagram

\section{HASIL DAN PEMBAHASAN}

a. Langkah-langkah Pembuatan Sistem

Langkah dalam pembuatan sistem ini menggunakan metode waterfall. Adapun tahapan yang ada pada metode sebagai berikut :

1) Analisis Kebutuhan/Requirement Analisis

2) Desain Sistem/System Design

3) Impelementasi/Implementation

4) Integrasi Pengujian/Integration and Testing

5) Operasi dan Pemeliharaan/ Operation and Maintenance

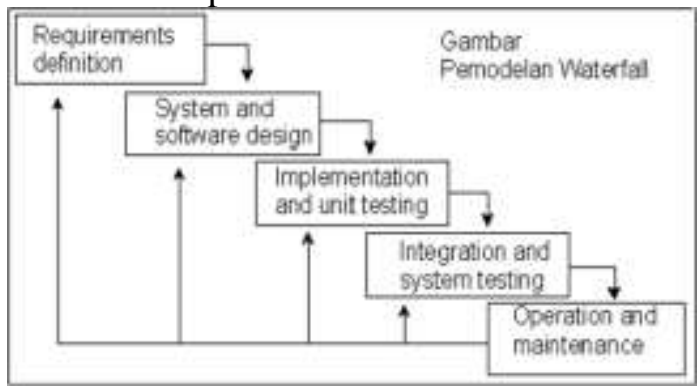

Gambar 7. Metode Waterfall

b. Hasil Tampilan Aplikasi

1) Tampilan Antarmuka Halaman Utama Admin

Tampilan dibawah ini adalah tampilan halaman utama dari admin saat melakukan login.

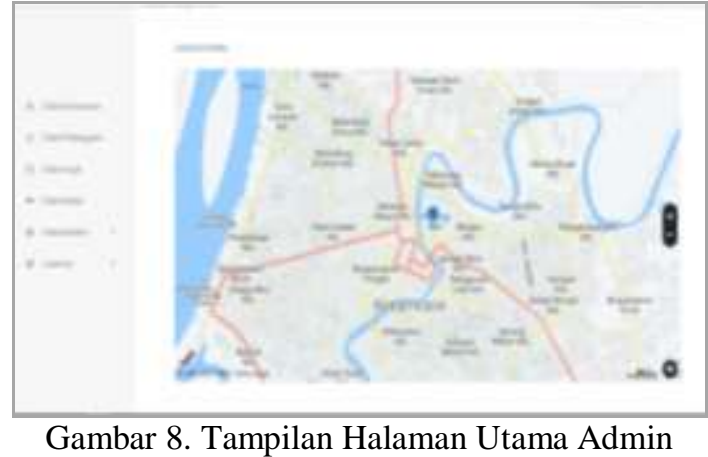

2) Tampilan Antarmuka Halaman Pelanggan

Tampilan dibawah ini adalah tampilan halaman utama dari pelanggan saat melakukan login.

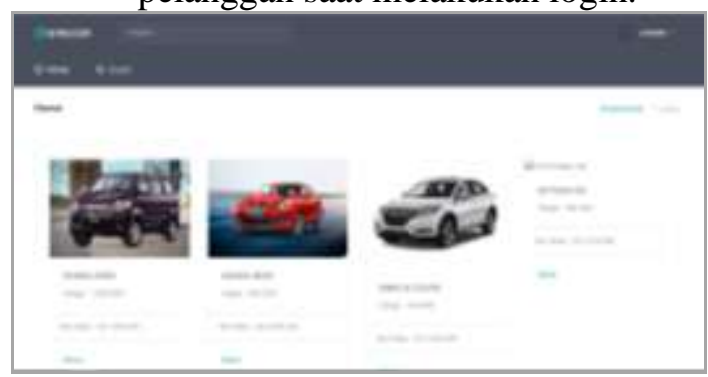

Gambar 9. Tampilan Halaman Utama Pelanggan

3) Tampilan Antarmuka Halaman Transaksi Berhasil

Tampilan dibawah ini adalah tampilan halaman yang akan tampil jika pelanggan telah berhasil melakukan transaksi.

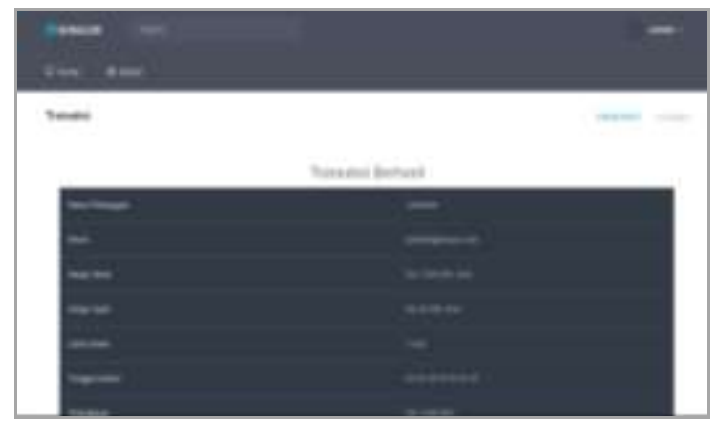

Gambar 10. Tampilan Halaman Transaksi Berhasil

\section{KESIMPULAN}

Setelah melalui beberapa tahapan dan pembahasan penelitian ini untuk menghasilkan aplikasi rental mobil pada CV. Rahayu Rental, dengan melihat dari semua permasalahan, analisis, perancangan dan pembuatan sistem maka dapat ditarik kesimpulan diantaranya :

a. CV. Rahayu Rental Banjarmasin sekarang telah memiliki website 
dengan informasi yang lengkap mengenai data mobil, biaya, cara daftar dan cara transaksi sehingga masyarakat dapat mengetahui dan mudah untuk menggunakan jasa $\mathrm{CV}$. Rahayu Rental Banjarmasin.

b. Aktivitas transaksi dan pembukuan pada Rahayu Rental dapat tercatat dengan rapi dan efisien dalam bentuk media maupun tenaga.

c. Mobil yang dirental dapat dengan mudah diketahui lokasi nya sehingga mengurangi resiko kehilangan.

b. Pembuatan laporan sudah terkomputerisasi sehingga lebih efektif dan efisien.

\section{REFERENSI}

[1] M. Rasyidan, A. and M. I. Firdaus, "Perancangan Aplikasi Absensi Kelas Berbasis SMS Gateway," Al Ulum Jurnal Sains dan Teknologi, vol. 2, no. 2477-4731, pp. 52-57, 2016.

[2] A. S. Sitanggang and A. W. Sutardi, "Sistem Informasi Penyewaan Rental Mobil di CV. Surya Rental Mobil Bandung," JATI : Jurnal Teknologi dan Informasi UNIKOM, vol. 1, no. 20882270, p. 5, 2014.

[3] D. C. Mahendra, T. Susyanto and S. Siswanti, "Sistem Monitoring Mobil Rental Menggunakan GPS Tracker," Jurnal Ilmiah SINUS, vol. 16, no. 16931173, p. 2, 2018.

[4] M. H. Nuri, "Sistem Informasi Manajemen Rental Mobil Berbasis Web," Program Studi Teknik Informatika Fakultas Sains dan Teknologi UIN Sunan Kalijaga, Yogyakarta, 2014. 